\title{
The specific vulnerability of plant biodiversity and vegetation on Mediterranean islands in the face of global change
}

\author{
Frédéric Médail ${ }^{1}$
}

\begin{abstract}
The numerous Mediterranean islands $(>10,000)$ are very important from a biodiversity point of view, both in term of plant species (numerous endemics, presence of 'climate relicts') and of ecosystems' assemblage. These patterns can be explained by complex interactions between a highly heterogeneous historical biogeography and ecological processes related to diverse island conditions. Furthermore, most of the ups and downs of this biodiversity were closely linked with human pressures which have changed many times through the long socio-ecological history of these island landscapes since the Neolithic period. At present, insular plant biodiversity and rural landscapes are threatened by diverse global environmental changes related to urbanization, habitat fragmentation, unsustainable tourism and other practices (e.g. overgrazing, forest fires), and by other more recent drivers such as climate warming and aridification, sea-level rise and biological invasions. Some of these impacts will be exacerbated on islands because of no (or highly limited) adjacent areas of expansion, notably on the smallest ones (i.e. size $<$ ca. 1000 ha). With regards to the biome crisis facing the Mediterranean basin and induced by human activities, islands constitute key ecological systems and 'current
\end{abstract}

Electronic supplementary material The online version of this article (doi:10.1007/s10113-017-1123-7) contains supplementary material, which is available to authorized users.

Frédéric Médail

frederic.medail@imbe.fr

1 Institut méditerranéen de biodiversité et d'écologie marine et continentale (IMBE), Aix Marseille University/CNRS/IRD/ AU. Campus Aix, Technopôle de l'Environnement ArboisMéditerranée, 13545 Aix-en-Provence cedex 4, France refugia' to ensure the long-term preservation of coastal plant biodiversity. They also represent fascinating ecological systems to disentangle the role of environmental versus human pressures on spatially simplified communities of the Mediterranean coastal areas. Future detailed studies of these 'natural island microcosms' could greatly improve our knowledge of the functional and evolutionary processes induced by rapid environmental changes in this region.

Keywords Coastal ecosystems · Human impacts · Insular biogeography $\cdot$ Land use changes - Mediterranean region . Sea-level rise

\section{Introduction}

The complex historical biogeography and the profound environmental heterogeneity explain the high diversity of landscapes and vegetation types on islands of the Mediterranean basin, one of the 35 terrestrial biodiversity hot spots of the world (Médail and Myers 2004). The associated high levels of biodiversity and ecological complexity have favoured the emergence of functional uniqueness for several ecosystems and plant communities that occur nowhere else. With about 10,000 islands and islets (ca. 250 regularly inhabited by humans), the Mediterranean Sea represents one of the regions of the world with the most islands and archipelagos. Its islands contain a significant component of Mediterranean biodiversity, notably a number of range-restricted species and peculiar vegetation types (e.g. Vogiatzakis et al. 2008; Médail 2013, 2017). Past geographical and climatic changes, combined with current environmental heterogeneities, have moulded unusually high levels of biodiversity and biogeographical complexity. The diversity of ecosystems 
of Mediterranean islands is also linked to the long-lasting influence of humans as 'designers' of landscapes, who have shaped vegetation dynamics through burning, cutting, grazing and ploughing (Blondel 2008). More recently, the biodiversity and functioning of these ecosystems were threatened by global environmental change, notably ecological footprint due to human expansion, climatic and sealevel changes, and biological invasions.

\section{The diversity of Mediterranean islands}

Mediterranean islands are a kaleidoscope of environmental and biotic conditions (Médail 2017). This is due to the wide range of sizes (from the largest island of Sicily covering $25,700 \mathrm{~km}^{2}$ to small islets a few dozen square metres in size), in altitude (from Mt. Etna, $3342 \mathrm{~m}$ a.s.l. to flat islets only one metre a.s.l) and in remoteness, all of which represent key parameters in island biogeography. There are a total of 157 large islands exceeding $10 \mathrm{~km}^{2}$ (1000 ha) in size, of which $86(55 \%)$ are located in Greece (Médail 2017). Forty nine islands cover more than $100 \mathrm{~km}^{2}$, of which 36 cover more than $200 \mathrm{~km}^{2}$. Small islands with a surface area less than $10 \mathrm{~km}^{2}$ are the most common, and there are several thousands of such islands. Most islands belong to the Greek archipelago with ca. 7600 islands and islets in the Aegean Sea, more than $90 \%$ of which cover less than $10 \mathrm{~km}^{2}$ (Triantis and Mylonas 2009), and ca. 300 islands and islets in the Ionian Sea. Croatia is the second country in terms of the number of islands $(n=1246)$, whose 79 islands of more than $1 \mathrm{~km}^{2}$ and 653 small islands and islets have vascular vegetation (Nikolić et al. 2008).

Nearly all Mediterranean island ecosystems are under the influence of the Mediterranean climate (Fig. 1), except some parts of the high mountains of Corsica that contain subalpine and alpine vegetation belts with euro-siberian and even arctic-alpine plants (Gamisans 1999). The insular vegetation types usually considered as 'typically Mediterranean' are the evergreen and sclerophyllous shrublands and forests under semi-arid $(400<P=$ annual rainfalls $<600 \mathrm{~mm})$ or sub-humid $(600<P=$ annual rainfalls $<800 \mathrm{~mm}$ ) bioclimates, corresponding to thermomediterranean and meso-mediterranean vegetation belts (Table suppl.); Fig. 1). If deciduous trees were the cornerstones of ecosystem dynamics during the post-glacial period, notably in the northern Mediterranean, these forests were severely impacted by humans and their livestock (Quézel and Médail 2003; Médail 2008). This is the case of the forests of Valonia oak (Quercus ithaburensis subsp. macrolepis) in the central Aegean islands, of the Downy oak forest (Quercus pubescens) in western Corsica or of the mixed Quercus congesta and cork oak (Quercus suber) forests in Sardinia (Médail 2017).
The existence of endemic or range-limited plant species can determine specific patterns of insular vegetation types and landscapes. On large islands, plant endemism ranges from 8 to $17 \%$, whereas the total number of taxa is greater than expected, usually between 1600 and 2800 species and subspecies (Table 2). In mountain ranges of islands, the level of endemism is higher: above $1700 \mathrm{~m}$ a.s.l. endemics represent 35-40\% of the vascular flora in Corsica and in Crete. Each island has its own specificities of vegetation even if major physiognomic structures may appear similar from one island to another. They are mostly covered by typical vegetations of the thermo-mediterranean and mesomediterranean belts, whereas the upper vegetation levels are restricted to the summits of the largest islands, notably Corsica, Sicily, Crete and Cyprus.

\section{Biogeography of Mediterranean islands, museum and cradle of plant diversity}

The history of the Mediterranean basin setting is highly complex both from a geologic and a climatic point of view (e.g. Woodward 2009; Fig. 2). Tectonic events and the Messinian salinity crisis-which induced an almost complete desiccation of the Mediterranean Sea between 5.96 million years (Ma) and 5.33 Ma (CIESM 2008) (Fig. 2c) have strongly influenced the palaeogeography of the region, and thus the biogeographical history. If some preMediterranean plant taxa exist since the Eocene (ca. 40 Ma: Fig. 2a), the main diversification of the Mediterranean species took place during (1) the Miocene (Fig. 2b), notably in conjunction with the collision of the African and Eurasian plates with the Arabian plate and (2) the Pliocene with the onset of the Mediterranean climate (Fig. 2d). Recurrent episodes of species dispersal and vicariance have occurred between the eastern and western Mediterranean regions in relation to the several marine regressions or transgressions and the ongoing rise of Alpine and Atlas orogenesis (e.g. Mansion et al. 2008).

The majority of Mediterranean islands are 'continental islands' sensu lato (including continental shelf and continental fragments according to Whittaker and FernándezPalacios 2007), i.e. they were once part of the continent before their separation and drifting (such as the small continental sub-plate of Corsica-Sardinia which separated during the Oligocene), or during various episodes of low sea level (marine regression). Most of them have become progressively isolated from the mainland and each other by a complex combination of tectonic and glacio-eustatic processes. But there also are a few Mediterranean 'oceanic islands' in the geological sense, such as the volcanic islands (see below) and notably Cyprus which emerged from the bottom of the sea and has probably never been 


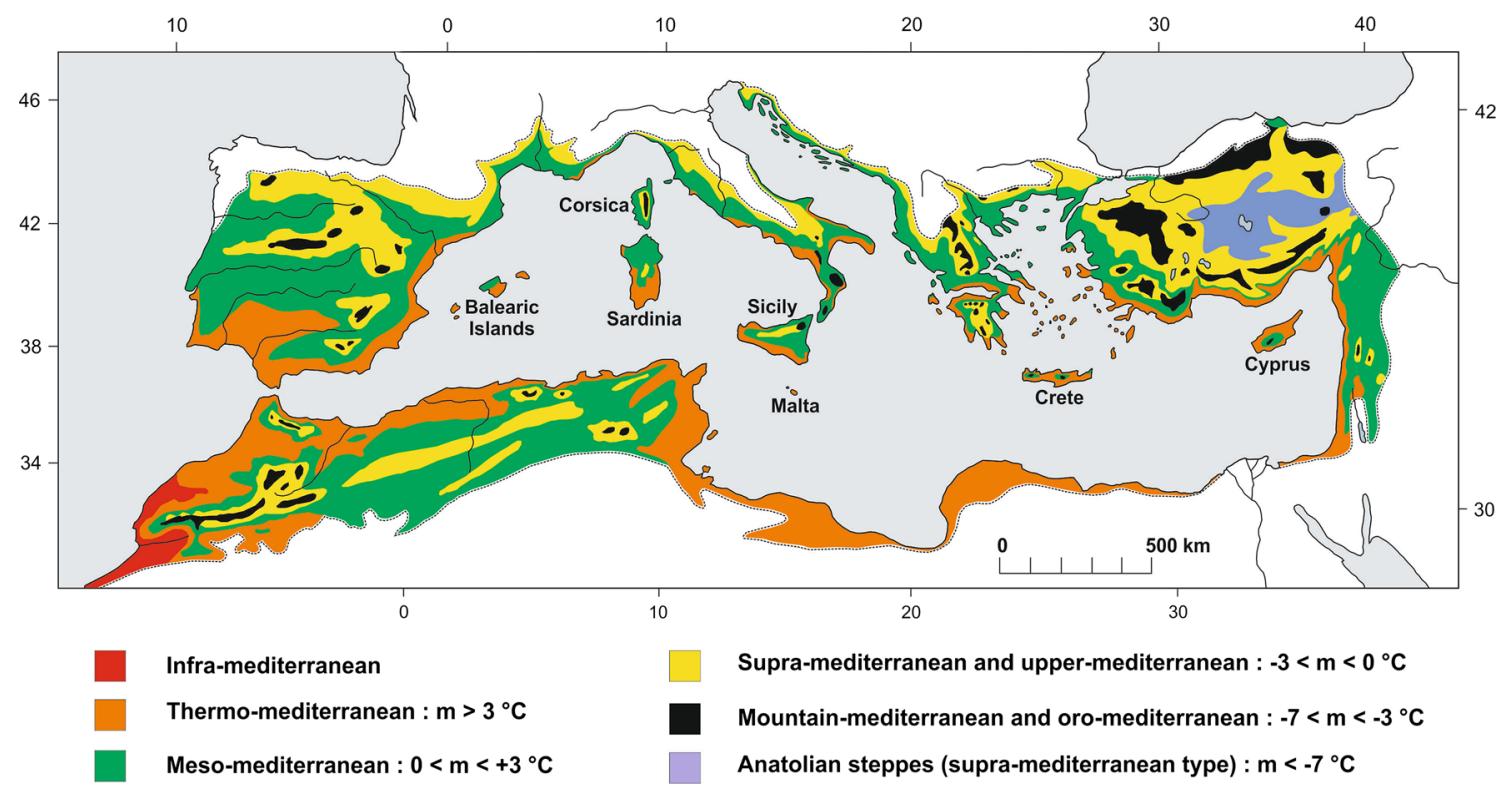

Fig. 1 Schematic distribution of major vegetation types in the Mediterranean region, according to vegetation and bioclimatic criteria, notably the mean minimum temperatures of the coldest month $(m)$ of the year (see Quézel and Médail 2003; Médail 2008)

connected with the mainland. Vigne $(1999,2014)$ also proposed to distinguish a 'true island' as an island which was 'separated from the mainland for a substantial period of time, throughout the Late Glacial and the Holocene' (Vigne 2014), i.e. for about 20,000 years (Fig. 2e). This category encompasses about 20 islands or archipelagos, including the five large islands (Cyprus, Crete, Sardinia, Corsica and Mallorca), but not Sicily which is a special case because of its proximity to the mainland and the existence of a land connection during the marine regression of the Würm glacial.

\section{Climatic and eustatic changes of the Pleistocene}

The onset of Mediterranean climate is relatively recent, and palaeoclimatic reconstructions demonstrate that cooling and drying, with a combination of summer drought and mild winter temperatures, have appeared quite rapidly in Late Miocene or Early Pliocene (c. 5-3 Ma) (e.g. Tzedakis 2009). Severe cooling episodes during the late Pliocene and the Early Middle Pleistocene have profoundly affected the biogeographical footprint of Mediterranean lineages with the extinction of several megathermic and warm-temperate taxa.

Drastic marine regressions that have occurred during the recurrent glacial episodes, between the end of the Pliocene and until the last glacial maximum (LGM, ca. $18,000 \pm 2000$ years BP), have induced more or less severe droppings of sea level (Fig. 2e). The last eustatic change in the LGM, with a lowering of sea level between
100 and $150 \mathrm{~m}$ below, has favoured the migration of a more competitive cool-temperate mainland flora to the offshore islands. This is the case of many Aegean islands, except Rhodes, the Cyclades and the Crete-Karpathos island group, which remained completely isolated throughout the Pleistocene. These land-bridge connections explain some biogeographical affinities between floras that are currently distant and isolated. Although long-distance dispersals of seeds by wind, birds or marine currents almost certainly played a certain role in Mediterranean island colonization, well-documented evidence of these processes are quite rare, except for some common halophytes (Westberg and Kadereit 2009).

\section{Glacial refugia for plants}

Glacial refugia are areas sheltered from the strong climatic deteriorations during ice ages, where species could survive by avoiding the consequences of severe cold and aridity during glacial events like the LGM. Phylogeographic and palaeoecological studies show that these refugia represent crucial areas for the long-term persistence and dynamics of modern biodiversity in temperate regions such as the Mediterranean basin (Médail and Diadema 2009). The six large Mediterranean islands represent major refugia areas and sanctuaries of old, often mid-Tertiary floras with numerous 'climate relicts' (Woolbright et al. 2014), i.e. plants characterized by a prolonged evolutionary standstill. The relictual nature of Mediterranean island floras is well supported (1) by the 

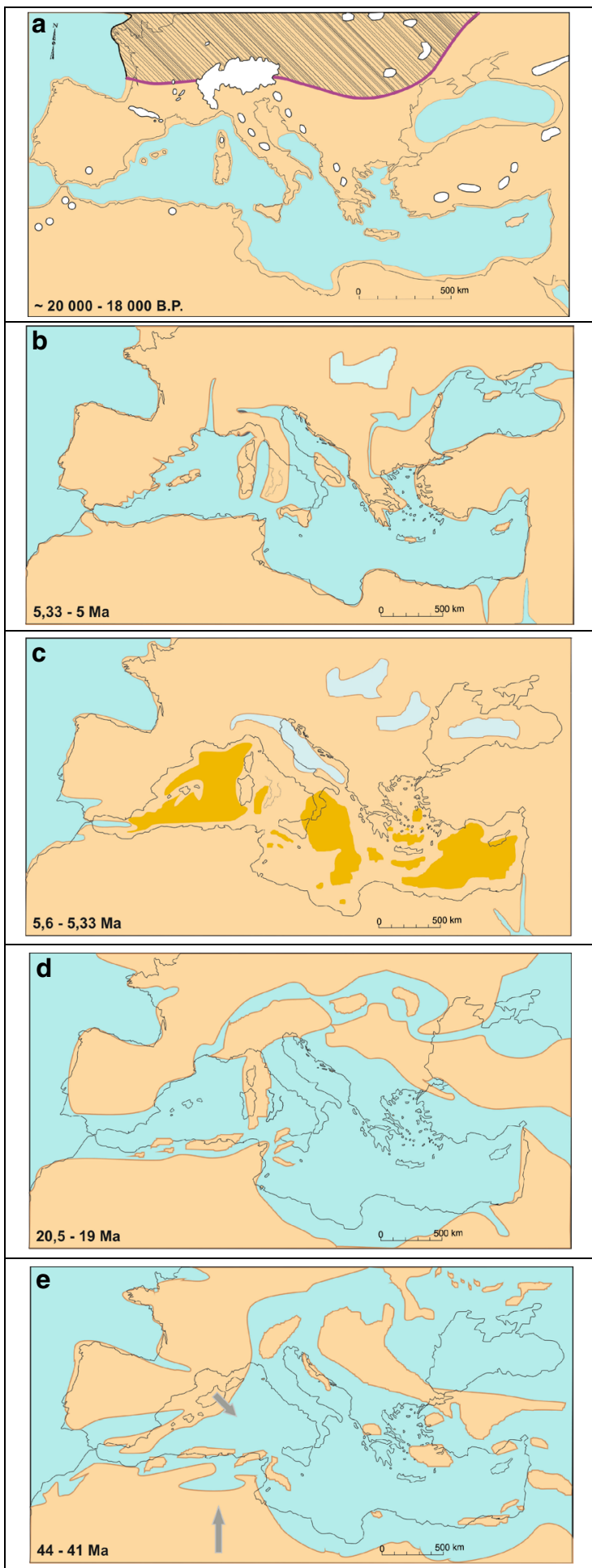

\section{Last Glacial Maximum}

Ultimate episode of severe cooling, after the multiple PlioPleistocene Glacial-Interglacials cycles (onset of major glaciations: $\sim 2.8 \mathrm{Ma}$ to $\sim 0.92 \mathrm{Ma}$ ).

$\Rightarrow$ Drastic changes in vegetation structure and composition with several regional extinctions (Carya, Pterocarya) or regression of temperate-warm plants; importance of islands as glacial refugia for warm-tolerant plants (eg. Zelkova, Liquidambar, Phoenix, Woodwardia).

$\Rightarrow$ Eustatic seal-levels changes connecting numerous islands with the coast or between them (e.g. Corsica and Sardinia).

\section{Early Pliocene (Cenozoic, Neogene)}

Gradual climatic changes towards the Mediterranean climate, with a significant drop in temperature and a marked seasonality in thermal and rainfall regimes (3.6 to $2.4 \mathrm{Ma}$ ), with the stabilization of the summer drought at $\sim 2.6 \mathrm{Ma}$.

$\Rightarrow$ Progressive reduction of the tropical flora (along the coasts, extinction of Avicennia mangroves and then marshy forests with Taxodiaceae), and replacement by a Mediterranean sclerophyllous flora ( 3.6 Ma) with a clear latitudinal zonation; diversification of several genera (Abies, Pinus spp., Quercus cf. ilex, Olea, Phillyrea, Cistus, Erica).

\section{Messinian salinity crisis (Cenozoic, Neogene)}

Two successive episodes of dessication of the Mediterranean sea due to its isolation from the Atlantic Ocean induced by tectonic events; the $1^{\text {st }}$ episode (5.96 to $\left.5.6 \mathrm{Ma}\right)$ was less severe than the $2^{\text {nd }}$ one ( 5.6 to $5.33 \mathrm{Ma}$ ).

$\Rightarrow$ Several terrestrial connexions between Eurasia and Africa and between mainland and islands; migration of steppic plants dominated by Poaceae (e.g. Lygeum spartum) to the North of the Mediterranean.

\section{Early Miocene (Cenozoic, Neogene)}

Existence of a tropical climate with a pronounced dry season. $\Rightarrow$ Coexistence of mixed vegetations with macrothermous (palms, Bombacaceae, Sapindaceae) and mesophilous (Acer, Alnus, Carpinus) taxa; increase of Mediterranean plants ( 50 species) in several geofloras of Eurasia.

\section{Middle Eocene (Cenozoic, Palaeogene)}

Tropical and then paratropical climates.

$\Rightarrow$ Evergreen and laurel forests including few preMediterranean plants (Chamaerops, Myrtus, Laurus, Pinus, Platanus, Rhamnus, Smilax); existence of a Madro-Tethyan sclerophyllous flora (Arbutus, Quercus, Rhus) shared between North America and Eurasia due to the North Atlantic Land Bridge ( $\sim 50$ to $25 \mathrm{Ma})$.

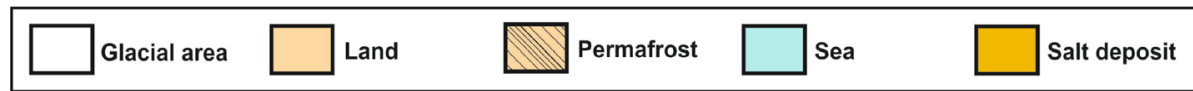

Fig. 2 Palaeogeographical maps of the Mediterranean basin between the first part of the Cenozoic (middle Eocene period, ca. $44 \mathrm{Ma}$ ) and the Last Glacial Maximum (Holocene, ca. 20,000 years BP) (after
Diadema and de Beaulieu 2011, modified), and correspondance with the main changes of flora and vegetation 
presence of palaeoendemics restricted to one or few of these islands, notably several monotypic genera such as Morisia, Naufraga or Petagnaea (Table suppl.), and (2) by the existence of some relicts originating from the subtropical environments of the Tertiary, such as the Tethysian-Palaeotropical fern Woodwardia radicans in Corsica, Sicily and Crete or Zelkova abelicea, a relict tree endemic of the Cretan mountains (Bosque et al. 2014).

\section{Recent plant diversification}

While Mediterranean islands have served as important Tertiary and glacial refuges, their role in the local and more recent differentiation of plants is at least as important. All islands possess highly polymorphic species and vicariant endemic plants issued from more or less recent speciation events (e.g. Limonium, Centaurea) (Rosselló 2013). Isolation and environmental heterogeneity have favoured diverse evolutionary processes of gradual speciation of plants, such as genetic drift or adaptive radiation. Chromosomal rearrangements and hybridization have also played a key role in the rapid speciation of several endemic lineages in Mediterranean islands (Verlaque et al. 1995). In central Mediterranean islands, the taxa of the Centaurea cinerea group had long been assumed to be old relics; however, molecular dating now indicates more recent (less than 250,000 years) allopatric diversification (Hilpold et al. 2011). Some well-studied examples are also found in the Aegean islands like the obligate chasmophytes of Erysimum sect. Cheiranthus (Snogerup 1967) and the Nigella arvensis complex, where the history of isolation of these multiple islands determines pronounced random plant differentiation by genetic drift following fragmentation of a former contiguous distribution area, or after long-distance dispersal (Bittkau and Comes 2005).

Therefore, if Mediterranean island floras are in part relictual, their evolutionary dynamics are probably underestimated, in particular on small islands subject to harsh and stochastic environmental conditions.

\section{Past vegetation dynamics of Mediterranean islands during the Holocene in relation to climatic changes and human impacts}

\section{First impacts by man and Holocene climatic changes}

During the Pleistocene and even more so in the Holocene, vegetation dynamics have been strongly affected by human use and associated disturbances. Indeed, the history of the
Mediterranean island environment is intimately linked to that of human societies (e.g. Ghilardi 2016). The evidence of the earliest date of island colonizations by prehistoric people in the Mediterranean - a 'Palaeolithic seafaring by Stone Age sailors' (Simmons 2014)—is still disputed (Broodbank 2006; Leppard 2014; Runnels 2014), because it is often difficult to assess whether human occupation was only temporary along the coasts or has become more permanent. The first tangible traces of extended human presence on a Mediterranean island seem to exist on Cyprus around 12,500 years ago (Table 1) (Zazzo et al. 2015), and the development of agriculture has occurred between 11,200 and 10,600 years ago (Vigne et al. 2012). In the western Mediterranean, the oldest sporadic settlements on islands date back to the Mesolithic (ca. 10,000 years ago in Corsica, Sardinia), but with a gap until the Early Neolithic when these two islands were re-colonized during the initial phase of neolithization, around 7700 years ago (RowleyConwy et al. 2013). Genetic analysis of the genome of human populations bordering the Mediterranean also supports the hypothesis that a maritime route and island hopping was prominent and that Neolithic migrants have reached southern Europe, first through an Anatolian route and then, by the sea, through the Dodecanese islands, Crete and Italy (Paschou et al. 2014), in accordance with archaeological findings.

Since the Neolithic revolution, landscapes have been profoundly shaped by humans for almost 10,000 years ago in the eastern Mediterranean, and for around 7500 years ago in the western part (Zeder 2008), in relation to the timing of human colonization (Table 1). The ecological consequences of these first human impacts on Mediterranean biodiversity can be seen in different perspectives. Broadly, two contrasting views have been proposed (Blondel 2006): the 'ruined landscape' or 'lost Eden' theory advocated by J.V. Thirgood and D. Attenborough for the whole Mediterranean biota versus the 'pristine savanna-like landscapes' proposed by O. Rackham after his historical landscape studies in Crete (Rackham and Moddy 1996). The 'ecological reality' is more complex and certainly positioned between these two extremes.

A second factor that has shaped plant diversity and landscapes on islands is the progressive aridification of the climate during the Holocene. Overall, human action, amplified by progressive warming and drying of the climate, has probably led to the extinction of several mesophilous species and communities, as well as to the disruption of formerly large plant populations into small and isolated fragments as a consequence of habitat deterioration. In Crete, some pollen assemblages suggest that the driest conditions occurred between 9375 and 8310 years ago, with a vegetation composed by open deciduous-oak forest (Bottema and Sarpaki 2003). In the central and western Mediterranean, dry 
conditions arrived more recently during the middle Holocene, ca. 4500 years ago (Magny et al. 2012). In the Balearic Islands, aridification induces the replacement of mesophyllous forests with Corylus, Alnus, deciduous Quercus, Buxus balearicus and perhaps Fagus, by xeric-type communities combined with an increase in sclerophyllous species as this occurred in Sicily around 4500-4000 years ago, even if these ecological successions are not fully synchronous between the two islands (Pérez-Obiol and Sadori 2007).

\section{Transformation of island landscapes during the Antiquity}

During the Antiquity, human impact on island ecosystems was undoubtedly profound, affecting especially two types of natural habitats: forests and wetlands marshes. The ancient destruction of forests by humans for wood and the alteration of forest regeneration due to overgrazing constitute a common pattern in the whole Mediterranean area (Thirgood 1981; Quézel and Médail 2003). Alteration of forests first occurred in the low plains in order to increase cropland, and deciduous forests with various keystone species of oaks were particularly impacted. In Greece, deciduous forests were largely converted to permanent crops or olive groves during the first millennium before our era (Gerasimidis 2005). This is the case of the forests of Valonia oak (Quercus ithaburensis subsp. macrolepis) in the central Aegean islands. In the western Mediterranean, oak forests of Quercus pubescens in the Plaine orientale of Corsica were severely impacted by humans (Gamisans 1999). Also the mixed Quercus congesta and cork oak (Quercus suber) forests of central and western Sardinia, which probably represent the remnants of formerly more extensive stands, were often turned into forest-savannahs similar to the Iberian dehesas (Quézel and Médail 2003).

Coastal marshes were precociously drained and exploited because these flat areas with a deep fertile soil were coveted as farmland especially as malaria was rampant. In the Aegean islands, the originality of the impact on wetlands relies on its precocity, because the favourable lands were scarce compared to the vast areas of the continental Greece (Brun 1996). No one doubts that this early pattern of land use of wetlands has occurred also on many other Mediterranean islands. Moreover, coastal wetlands were impacted from ca. 7000 years ago onwards by a continued intrusion of sea water caused by the mid-Holocene marine transgression (see below) inducing salinization processes.

Another originality within the structure of agriculture on island is related to the space constraints imposed by the small proportion of the plains and the existence of often mountainous landscapes. These topographical constraints have led people, since the Antiquity, to arrange the slopes in cultivation terraces to stabilize the soil and to improve its fertility. Indeed, numerous small and medium islands 
were almost totally converted by this mode of land use. This is particularly the case of the circum-Sicilian islands and also the Aegean islands (Brun 1996).

Probably, the main environmental changes on island landscapes were realized during the Antiquity, whereas the changes after the Middle-Ages till pre-industrial era vary considerably from one island to another and over time, depending on its topographical features and on the various practices of land uses.

\section{Island plant biodiversity in the face of current global environmental change}

The dynamics of landscape and vegetation on Mediterranean islands depend both on specific environmental constraints (climate and soil types) and on local socioeconomic trends induced by humans. First, the particular vulnerabilities of Mediterranean climate are related to its seasonality and the severe dry summers. This induces severe and contrasted stress on species and communities, since organisms must often cope with drastic temporal unpredictable variations in climate and resource availability of soils (e.g. Médail 2008). In addition to this harsh environmental context, the ancient impact of man since the Neolithic has profoundly altered the composition, structure and function of these island ecosystems. With the current global environmental trends, the situation is now changing rapidly with a new magnitude of impacts on island ecosystems and biodiversity.

\section{Widespread human impacts and land use changes}

Most of the ups and downs in Mediterranean ecosystems are closely linked with human population pressures which have changed many times through the long common history of ecological systems and human societies. Therefore, the dynamics of human populations will still be the determining factor in the future of the Mediterranean biodiversity (Blondel and Médail 2009).

Beginning in the nineteenth century and with a constant acceleration throughout the last century, major land use changes on large and medium islands can be explained by the widespread collapse of the 'traditional Mediterranean tryptich' named ager-saltus-sylva (agriculture, pastoralism, forestry) which had moulded insular landscapes during several centuries, and even millennia. Until the midtwentieth century, natural resources were indeed crucial for island population, notably for food, livestock, nutraceutical and healing compounds, or various usages (fibre, weaving, resin). These needs were huge when one considers, for example, that only during one year (1867) more than 7000 tonnes of wood and coal were consumed in Palma de
Mallorca for domestic and artisanal uses (Mayol 1995). Caused by the end of the nearly specific economies on islands, changes in agricultural and livestock farming extending inland have induced in many cases a reduction in pressures on natural resources. Therefore, there is a general increase in areas covered by sclerophyllous shrubs ( $m a$ torrals) and forests, induced by the abandonment of cultivated terraces that were formerly the rivet of agricultural landscapes on steep and mountainous islands (e.g. Cerabolini et al. 1996, for Elba in Tuscany; Petanidou et al. 2008, for Nisyros in the Aegean).

Today, the major islands are usually characterized by a slight increase in permanent human population, whereas the medium-sized islands-except some hotspots of tourism such as Corfu and Djerba-are subject to demographic decline. But even for large islands, disparities are strong between a very densely populated island like Malta (1330 people $/ \mathrm{km}^{2}$ ) and a less-populated island as Corsica (36 people $/ \mathrm{km}^{2}$ ). Furthermore, since the $1960 \mathrm{~s}$, tourism on islands has increased everywhere, with a paroxysm on some Balearic Islands (Mallorca and Ibiza) where a peak was reached in 2000-2001 with 11 million tourists. This pressure has induced strong urban development, concentrated along the coasts, which is threatening or even destroying several fragile ecosystems such as sand dunes and wetlands, and to a lesser extent coastal rocky habitats. For example, on the Greek island of Skiathos (N. Sporades), tourism development since the 1970s has caused a $80 \%$ reduction in these coastal ecosystems (Economidou 1995).

Nevertheless, these environmental trends cannot be generalized for all islands. For example, the ecosystem dynamics after land abandonment and increased grazing pressure are still uncertain in many Mediterranean islands (e.g. Rühl and Pasta 2008; Schaich et al. 2015). In some cases, the vanishing of traditional agricultural activities and landscapes has induced severe soil erosion or the rapid extinction of many ruderal endemics and several particular archaeophytes (La Mantia et al. 2011). Throughout the Aegean archipelago, the collapse of cultivation practices on terraces after the beginning of the twentieth century has induced major landscape changes, and the near disappearance of traditional crops since the 1960s: lentils on Samos and Lesvos, wheat on Chios, beans on the Cyclades (Boillot 1995). On most of these islands, the unique terraced landscapes have significantly decreased. In the western part of Crete, human immigration from arid mountains has led to the decline in agricultural land area by almost 40\% between 1945 and 1990, favouring the recovery of forest ecosystems dominated by the coniferous Cupressus sempervirens and Pinus brutia. The same process occurs on the Balearic Islands where drastic changes have occurred (Marull et al. 2015). Forests covered by 
Aleppo pine (Pinus halepensis) multiplied their surface by more than five in Mallorca during the last century. Between 1971 and 1999, pinewoods increased from 55,000 to 115,000 ha in the Balearic Islands (Gil and Díaz-Fernández 2003). Similarly, holm-oak (Quercus ilex) forests have increased from 5000 ha to more than 10,000 ha in Mallorca, and from 900 to 2600 ha in Menorca since 1860 (Mayol 1995). In contrast, high shrublands and natural forests of eastern Sardinia have diminished by 35\% between 1955 and 1996, whereas pastures, burned low shrublands and reforested areas are progressing. Landscape dynamics are more heterogeneous in Corsica, and since the beginning of the twentieth century, land abandonment has induced a global increase in shrublands and forested areas. The afforestation rate reached only $17.6 \%$ in 1866 (i.e. 153,775 ha) against $58 \%$ currently (i.e. 507,000 ha), i.e. an increase of 3.3 in the surface of Corsican forests over a period of 150 years (Panaïotis et al. 2015). But this increase can be locally counterbalanced by frequent illegal fires, often linked to pastoral practices. Corsican rural area occupies still $80 \%$ of the land and sectors of traditional moving herds (transhumance) span more 130,000 ha throughout the mountain range (source: PNRC). Grazing is a well-known obstacle to forest expansion and regeneration, and a key driving force of ecosystem dynamics as it has been practiced on Mediterranean islands for millennia, shaping both the landscape and biodiversity pattern. This long history of grazing is intensified on most Greek islands, where large flocks of sheep and goats are usually free to graze. The case of small islets deserves mention. On many Aegean islets where no permanent inhabitants are present, people still leave herds of goats and sheep to graze for several periods of time (Bergmeier and Dimopoulos 2003). Until the last century, this practice was common in several other Mediterranean islets. These apparently uncontrolled practices can lead to overgrazing and even to desertification, i.e. land degradation under arid and semi-arid climates, of these fragile ecosystems (e.g. ArianoutsouFaraggiraki 1985; Papanastasis et al. 2002). Nevertheless, we must be cautious with the apparent desertification of the Mediterranean environments on larger islands. As demonstrated for the assessment of the natural environment in Cyprus between 1878 and 1960 (Harris 2012), the 'classic degradation thesis of deforestation' is often a simplified story of presumed desertification in order to justify the environmental policies of colonial authorities or centralized governments.

\section{Increasing forest fires}

Like grazing, forest fire has been a major driving force of Mediterranean ecosystem dynamics since the emergence of the Mediterranean climate, from 3.6 Ma ago. For the emblematic Corsican pine (Pinus nigra subsp. laricio), fires have played a key role in the functioning of these mountainous woodlands since this tree has survived mean fire-return intervals of 80 years over the last 13,200 years (Leys et al. 2014). Palaeo-fires contributed to the frequent dominance of shrubland on islands during the mid-Holocene (ca. 8000-7000 years ago) under dry conditions, as is the case of the Pistacia matorrals in Sicily and Malta (Djamali et al. 2013), and the dense Erica scoparia and E. arborea stands in north-eastern Sardinia (Beffa et al. 2016).

Fires can slow down the expansion of forest cover explained by the general collapse of traditional human practices on islands, in particular on persisting terraces that promote fast vegetation recovery. Thus, since ancient woodlands are scarce because of recurrent fires, shrub communities or steppic grasslands, still often dominate islands' landscapes. In Greece, the situation has been of particular concern for the last few decades given the increase in frequent intense wildfires. On Thasos Island, for example, a series of wildfires since 1984 has reduced forest cover from 61.6 to almost 20\% (Ranis et al. 2015). Furthermore, there often is spatial congruence between the most fire-affected microregions and the main cattle-rearing regions, like in Corsica. On this fire-prone island, 28,000 starting fires occurred between 1973 and 2004 (i.e. $\approx 1000$ starting fires/year) and a third of the total surface area of Corsica was burned in a period of 30 years.

Fire regime changes and the occurrence of extreme fire events (or 'megafires') are related to both land use change and climate change and involve multiple biotic and socioeconomic drivers (e.g. Pausas and Keeley 2014). It is difficult to disentangle their relative importance because the management of Mediterranean landscapes plays a major role to explain the probabilities of outbreak and spread of forest fires. In the western Mediterranean basin, a fire regime shift has occurred and fires are now less fuel limited and more drought-driven than before the 1970s (Pausas and Fernández-Muñoz 2012). In the future, increased drought could increase fire activity on most Mediterranean islands, with secondary effects of land degradation and erosion.

The aforementioned separation of key drivers related to global change is somewhat artificial. Their effects on plant biodiversity and ecosystem dynamics must be considered in interaction in order to better estimate the real consequences of these future changes.

\section{Biological invasions}

Worldwide, islands are known to be especially sensitive to biological invasions in both frequency and the degree of impact when compared to continents. Invasions often modify population dynamics, community structure, the 
composition and functioning of ecosystems and may trigger or accelerate the local extinction of indigenous plants. Also Mediterranean islands and islets are, in some places, seriously threatened by invasive plants, notably along coasts, in lowlands and riparian habitats (Hulme et al. 2007). But invasions in Mediterranean insular ecosystems are highly idiosyncratic and mainly depend on propagule pressure linked to human-mediated factors and water availability conditions (Vilà et al. 2006). The impacts depend on both the identity of the invasive plant and of the invaded island, suggesting that impact of invaders is context-specific (Traveset et al. 2008). The most invaded large islands are Corsica and Sardinia with a percentage of alien plants slightly higher than 17\% (466 and 508 alien taxa, respectively, according to Puddu et al. 2016), but the percentage of invasive plants is almost twice as high in Corsica $(21.2 \%)$ as in Sardinia (12.6\%). The other major islands are characterized by a lower number of alien taxa comprised between 6.7 and 9.5\% (Table 2).

Some the most invasive plants are the trees Acacia spp., Ailanthus altissima, the shrub Nicotiana glauca, the perennial herbs Cortaderia selloana and Oxalis pescaprae, the succulent plants Carpobrotus spp. and Opuntia ssp., and the liana Senecio angulatus. If larger islands are generally characterized by a greater habitat diversity and can support a wider richness of non-native plants, small Mediterranean islands are the most threatened by plant invasions (Pretto et al. 2012), because any invasion will induce disproportionate effects on the local carrying capacity of the ecosystems, including the persistence of narrow endemic plants. This is for example the case of the problematic survival of Silene hicesiae (Caryophyllaceae) on Panarea island (Aeolian archipelago, Sicily) that is currently threatened by the vegetative expansion of $A i$ lanthus altissima, and of Limonium sommierianum (Plumbaginaceae) on the island of Giglio (Tuscan archipelago, Italy) whose future persistence is jeopardized by the expansion of the succulent mat-forming Carpobrotus edulis.

All available data show the increasing importance of the alien flora in Mediterranean islands during the past century, with a higher proportion of introduced woody species (phanerophytes and chamaephytes) (Jeanmonod et al. 2011). Future scenarios suggest an exponential increase in naturalized and invasive plants on islands due to human activities and global warming. In Corsica, the number of naturalized plants ( $n=117$ taxa) could exceed the number of endemic ones ( $n=284$ taxa) in the next 30-50 years, and that of introduced plants could exceed the number at native one in the next centuries (Jeanmonod et al. 2011).

\section{Impacts of current climatic change}

The Mediterranean basin is considered to be one of the regions that will face the largest changes in climate worldwide (e.g. Giorgi and Lionello 2008). Scenarios of the IPCC show that this region will be particularly affected by temperature increase, decrease in rainfall and changes in seasonal patterns. With an expected temperature increase of $3-5{ }^{\circ} \mathrm{C}$ in the Mediterranean over twenty-first century, the potential evapotranspiration is expected to reach an average of $200 \mathrm{~mm}$ annually, which is equivalent to a loss of $50 \mathrm{~mm}$ in annual rainfall (Le Houérou 1990). The expected shifts in vegetation belts resulting from increased aridity and a $3{ }^{\circ} \mathrm{C}$ increase in temperature will be an upward shift of ca. $545 \mathrm{~m}$ (i.e. almost the amplitude of a vegetation belt) and a $50-80 \mathrm{~km}$ northwards shift in latitude (Médail and Quézel 2003). These impacts will be exacerbated on islands where no (or insufficient) areas are available for such shifts. The flora and vegetation of the alpine areas (i.e. mostly the oro- and alti-mediterranean belts: see Table suppl.) and the spatially restricted summit areas of mountain ranges will probably be the most threatened, as mentioned in the Lefka Ori massif in Crete

Table 2 Specific richness of native, endemic and alien plants of the six largest Mediterranean islands (Médail unpublished data from various sources)

\begin{tabular}{|c|c|c|c|c|c|c|c|}
\hline Island & $\begin{array}{l}\text { Area } \\
\left(\mathrm{km}^{2}\right)\end{array}$ & $\begin{array}{l}\text { Native plant } \\
\text { richness }\end{array}$ & $\begin{array}{l}\text { Endemic } \\
\text { richness }\end{array}$ & $\begin{array}{l}\text { Endemism } \\
\text { level }(\%)\end{array}$ & Endemic genera & $\begin{array}{l}\text { Number of } \\
\text { alien plants }\end{array}$ & $\begin{array}{l}\% \text { alien } \\
\text { flora/total flora }\end{array}$ \\
\hline Sicily & 25,426 & 2793 & 322 & 11.5 & Petagnaea, Siculosciadium & 292 & 9.5 \\
\hline Sardinia & 24,090 & 2149 & 290 & 13.5 & $\begin{array}{l}\text { Castroviejoa, Morisia, Nananthea, } \\
\text { Soleirolia }\end{array}$ & 508 & 17.4 \\
\hline Cyprus & 9251 & 1633 & 142 & 8.7 & Lindbergella & 152 & 8.5 \\
\hline Corsica & 8679 & 2237 & 284 & 12.7 & $\begin{array}{l}\text { Castroviejoa, Morisia, Nananthea, } \\
\text { Soleirolia }\end{array}$ & 466 & 17.2 \\
\hline Crete & 8261 & 2240 & 395 & 17.6 & Horstrissea, Petromarula & 162 & 6.7 \\
\hline $\begin{array}{r}\text { Balearic } \\
\text { islands }\end{array}$ & 4987 & 1551 & 140 & 9 & $\begin{array}{l}\text { On eastern islands: Femeniasia, } \\
\text { Naufraga, Soleirolia }\end{array}$ & 124 & 7.3 \\
\hline
\end{tabular}

Native plant richness includes the endemic richness 
(Kazakis et al. 2007). In Corsica, this is particularly the case of arctic-alpine species (ca. 25 taxa) located in the alpine vegetation belt (Contandriopoulos and Gamisans 1974).

But it is too simplistic to consider a single range shift of plant communities in response to global warming. As suggested for Mediterranean mammals, the effects of climate change on species distribution and communities may consist of changes in community structure (Maiorano et al. 2011). The extent to which many organisms will be able to cope with climate change is still largely an open question, especially because it is now taking place at an unprecedented rate in known climatic records during recent periods. Microevolutionary changes may occur rapidly in fitness related traits such as the flowering time of Mediterranean plants (Penuelas et al. 2002). Differential responses of organisms interacting in complex food chains or symbiotic associations may also disrupt interactions that are essential for ecosystem functioning such as pollination or seed dispersal by animals. This mutualism disruption was assessed for two declining relict plants of the Balearic Islands, Daphne rodriguezii and Cneorum tricoccon (Rotllan-Puig and Traveset 2016).

Climatic change is also a threat for the long-term persistence of island plant populations and communities linked to humid or mesophilous habitats, including some endemics that constitute the cornerstone of Mediterranean plant diversity. This is the case of two endemic species of the Apiaceae family restricted to the Balearic Islands. Apium bermejoi, a narrow endemic of Menorca located in a single area of $50 \mathrm{~m}^{2}$ where the ca. 100 individuals occupy only one square metre. As this critically endangered plant is vulnerable to prolonged droughts, its present decline is probably related in part to a series of dry summers (Moragues and Mayol 2013). The narrow ecological niche of the palaeoendemic Naufraga balearica, only distributed along a short section (ca. $15 \mathrm{~km}$ ) of the north facing slopes of the northern Majorcan coast, explains its current extreme rarity (Fernández-Mazuecos et al. 2014). Narrow microclimatic conditions of shade and humidity are crucial for the survival of Naufraga, and rapid climatic shifts could jeopardize its survival. In Cyprus, several populations of narrow endemics (e.g. Onosma caespitosa, Salvia veneris, Sideritis cypria) are also threatened by reduced rainfall by $20-40 \%$ and warming (Kadis, unpublished), both of which could modify their germination window in the fall like for other Cyprian endemics (Kadis and Georghiou 2010).

So far, despite multiple threats and the fact that a large number of endemic plant species are narrowly distributed on a single island with few small populations, there is only still few evidence for direct depletion or extinction of populations due to climate change. About six endemic species are known to have become extinct on the Mediterranean islands, of the 26 Mediterranean plants presumed to be totally extinct in this region (Médail and Iriondo, unpublished). Recent studies focused on the Cretan endemic Ulmaceae tree Zelkova abelicea (Fazan et al. ined.), and on some entire plant communities (e.g. Henne et al. 2015) showed that the ecological amplitude of many so-called 'temperate' species that thrive on Mediterranean mountains may have been underestimated since they could tolerate drier and warmer climates. Local persistence of Mediterranean plants, notably perennials, in diverse microhabitats may be due to multiple demographic strategies of persistence by longevity or regeneration, depending on the local or regional conditions (García and Zamora 2003). This is corroborated by the important role played by glacial refugia on islands (Médail and Diadema 2009), especially as the ecological and evolutionary implications of Pleistocene microrefugia or cryptic refugia (Mee and Moore 2014) are still underestimated on this large Mediterranean patchwork of islands. However, most plants interact with bioclimatic characteristics at a physiological rather than macroclimatic level (Curtis et al. 2016). Differences in small-scale habitats in a landscape may therefore explain species' ability to cope with drastic and changing climate. The high habitat heterogeneity of Mediterranean-type ecosystems may thus represent an 'ecological insurance' for the future persistence of plant species at local scale, allowing species to migrate locally in more favourable ecological niches. Nevertheless, at the scale of small islands, this may not be sufficient to ensure the survival of highly specialized plants. The future persistence of 'islet specialists' such as the small annual Nananthea perpusilla (Asteraceae) in some shady and humid patches under granitic rocks of some islets around Corsica and Sardinia may well be at risk if aridity is going to increase.

\section{Impact of sea-level rise}

Sea-level rise (SLR) is another important component of climate change threatening coastal ecosystems of large islands and the totality of terrestrial environments of flat islets. At the end of the last glacial period, a major consequence of climatic oscillation from cold to warm conditions was the melt of the Northern Hemisphere ice sheets causing a continuous eustatic sea-level rise worldwide. In the Mediterranean Sea, the main part of this marine transgression occurred before ca. 6000 years ago, with major disparities between areas. A recent review based on 917 relative sea-level data-points offers a strong and highquality Holocene relative sea-level framework for the western Mediterranean (Vacchi et al. 2016). Between ca. 7200 and 6200 years ago, the relative sea-level rose in 
south-eastern France from $-6.4 \pm 0.5$ to $-4.7 \pm 0.5 \mathrm{~m}$ a.s.l., but in southern Corsica and northern Sardinia the sealevel was lower: $-15.5 \pm 1.6 \mathrm{~m}$ at $c .7100$ years ago. The last 5000 years are characterized by a sub-linear sea-level rise (SLR) of about 2.5-1.5 m, with a rapid elevation until 1500 years ago, and then a stabilization close to the modern sea-level 500 years ago. Some intra-island phylogeographies-such as for the narrow Balearic endemic Senecio rodriguezii (Molins et al. 2009) - indicate an 'island beneath island syndrome', i.e. a split of populations into several isolated and genetically divergent lineages that are explained by the repeated cycles of sea-level changes during the Quaternary.

For the coming decades, a significant and rapid rise in global sea level (Galassi and Spada 2014). Tide gauge observations during the 1901-2010 period shows an average rate of SLR of $1.7 \pm 0.2 \mathrm{~mm}$ per year (Church and White 2011). For the period 1993-2014, altimetric data show that the global sea-level has risen with an average of $3.3 \pm 0.4 \mathrm{~mm}$ per year (Cazenave et al. 2014). However, this accelerated rise remains difficult to accurately estimate at the regional and local scales, because current SLR is the result of complex processes, with disparities between the different parts of the Mediterranean basin. Here, future regional scenarios by 2050 suggest that the total averaged SLR will be comprised between 9.8 and $25.6 \mathrm{~cm}$. This means than the regional rates of SLR may increase by a factor of 1-6 relative to the observed long-term rates.

Among the many harmful effects of SLR are the exacerbation of coastal erosion, the submersion of low elevation islands and flat coasts, and the salinization of coastal wetlands (Nicholls et al. 2016). For several oceanic islands of the world, Weigelt et al. (2016) suggest that current pattern of island biodiversity depends not only on the 'classical' process of immigration-extinction dynamics, but also of changes in island area, isolation and connectivity due to the SLR since the last glacial period (LGM). These past physiographical changes have strongly affected the composition of biodiversity, specially the number and proportion of endemic species.

A robust estimation of the biological consequences of these past SLR can be furnished by palaeoecological studies. On a small Mediterranean island (Cavallo, S. Corsica), Holocene sea-level changes played a significant role in loss of wetland biodiversity and ecosystem changes because of the increase in salinity caused by marine intrusions (Poher et al. 2017b). Analysis of coleopteran fossils preserved in a 7000 year sedimentary record showed that $60 \%$ of past wetland beetle fauna became locally extinct as a result of regime shift in this freshwater pond. The largest impoverishment occurred 3700 years ago when the relative Mediterranean sea-level rose more than $1.5 \pm 0.3 \mathrm{~m}$ (Poher et al. 2017a).
The effects of SLR might be less harmful for plant biodiversity on rocky island or coasts, because a slight altitudinal rise of halophilous communities and species towards the salt-tolerant habitats present just above could take place. Nevertheless, this shift may be limited by the presence of more disturbed habitats inland. Another worrying case is the vulnerability of 'pocket beaches' on islands. In Provence (France), Brunel and Sabatier (2007) found an $12.1 \pm 3.5 \mathrm{~m}$ retreat in the shoreline between 1896 and 1998, of which $5.8 \pm 3.5 \mathrm{~m}$ was caused by SLR. On small islands like Porquerolles (Port-Cros National Park) pocket beaches could almost completely disappear (from 75 to $97 \%$ regression of their present surface area) by 2100. Because of frequent coastal cliffs or rocky slopes blocking landward migration, typical plant communities and species of fixed maritime sands (e.g. the psammophytes Eryngium maritimum, Otanthus maritimus, Pancratium maritimum of the 'grey dunes') could become locally extinct on numerous small islands.

\section{Small Mediterranean islands, laboratories of global environmental changes}

The small islands (i.e. size $<$ ca. 1000 ha) and islets (less than $1 \mathrm{ha}$ ) represent the most common insular realm of the Mediterranean basin with several thousands of units. If most of the ecological studies carried out were devoted to large or medium islands (Médail 2017), smaller ones encompass a large range of environmental and biogeographical situations, forming suitable 'experimental laboratories' to test the putative consequences of global environmental changes in the face of several drivers. This is explained by the fact that, compared to the continent and larger islands, small insular communities and ecosystems are more sensitive to exogenous disturbances (storms, nesting seabirds, invasive species) and to environmental stochasticity which often promote rapid and contrasted ecological dynamics. The detailed example of the small islands of south-eastern Tunisia provides a good illustration of the vulnerability of an insular system to both a global driver (here the sea-level rise) and local human impacts (Box 1).

Finally, compared to large islands and continent, small islands often house large seabird colonies, notably gulls, that exert specific disturbance with a high pressure on ecosystems by modifying patterns and dynamics of plant communities. Seabirds are responsible for the energy inflow from sea to terrestrial ecosystems through guano, fish scraps and various rubbish. They often induce severe impacts because of physical (trampling, pulling-up, soil erosion, burrowing) and chemical (soil manuring induced by guano rich in phosphorous and nitrogen compounds, salt 
Box 1 Collapse of terrestrial biodiversity on the islands of Eastern Tunisia induced by sea-level rise and human impact

In the Gulf of Gabes (south-eastern Tunisia), they are thirty flat and sandy islands and islets distributed into three archipelagos: (1) the Kerkennah archipelago, located about eighteen $\mathrm{km}$ from the coastal town of Sfax and including two main islands (Gharbi, $48 \mathrm{~km}{ }^{2}$ and Chergui, $99 \mathrm{~km}^{2}$ ), and thirteen small satellite islands or islets for a surface area of around $4.5 \mathrm{~km}^{2}$ (Médail et al. 2015); (2) the Kneiss archipelago, consisting of one main island (El Bessila, $440 \mathrm{ha}$ ) and four vegetated islets, situated near the coast south of Maharè s (Médail et al. 2016); (3) the Djerba archipelago including the eponymous island, the greatest one of Tunisia $\left(526 \mathrm{~km}^{2}\right)$ situated at $1.5-2 \mathrm{~km}$ from the coast and surrounded by nine satellite islands or islets with vascular vegetation (Médail., unpubl. obs.). Maximum altitudes reach only $51 \mathrm{~m}$ a.s.l. for Djerba, and $13 \mathrm{~m}$ for the Kerkennah where lowland less than $2.5 \mathrm{~m}$ represents more than $50 \%$ of the islands' areas. The bioclimate is classifiied as upper-arid (with annual rainfalls between 200 and $300 \mathrm{~mm}$ ) according to the Emberger's classification. The current vegetation is mainly composed by halophilous plant communities with several shrubs of the Amaranthaceae family (genera Anabasis, Arthrocnemum, Atriplex, Halimione, Halocnemum, Salsola, Sarcocornia, Suaeda, etc.), some steppes with the Poaceae Lygeum spartum or Stipa capensis, and palm groves of Phoenix dactylifera

Geo-archaeological studies on these islands mention significant flooding of coastal lands and antique remains, up to two metres 2000 years ago (Slim et al. 2004). The magnitude of sea-level rise is currently estimated to $5.7 \mathrm{~mm}$ per year (Pirazzoli 1986). It is mainly explained by the active subsidence of the northern part of the Gabes Gulf (Oueslati 1995) and is exacerbated by the general rise in sea-level for over a century

The lithological context explains the high vulnerability to coastal erosion with a rapid retreat of the coastline and a continuous extension of the sebkhas (low, sandy and salty areas under the influence of the sea) at the expense of steppic areas and palm groves. On the Kerkennah islands, land salinization has led first to a sharp increase in sebkhas (+20\% between 1984 and 2011) and a $27 \%$ decline in palm groves equivalent to $26 \mathrm{~km}^{2}$ (Etienne et al. 2012). The next environmental phase was the increase in coastal marshes in place of sebkhas and the coastal indentation by channels (Slim et al. 2004). An even greater environmental collapse has occurred in the Kneiss archipelago: the four southern islets with a current total area of less of one hectare, surrounded by very reduced marine depth, comprise only 9 vascular plant species. In the Middle-Ages, though, they constituted a single elongated island, which hosted the monastery of Fulgence de Ruspe and a fairly large religious community (Trousset et al. 1992). The reconstruction of the contour of this 'palaeo-island El Laboua' based on the isobath $-2 \mathrm{~m}$ shows that its surface area was around 205 hectares, 1500 years ago (Médail et al. 2016). The collapse of terrestrial biodiversity induced by this huge surface retraction was probably considerable

Because of the scarcity of palaeoecological data, it is difficult to estimate the potential vegetation of these islands during the post-glacial times, with the onset of long-term aridification occuring between 5700 and 4600 years ago (Jaouadi et al. 2016). Nevertheless, the presence of ancient woody remnants of juniper (Juniperus phoenicea subsp. turbinata) and lentisc (Pistacia lentiscus) from a site of Djerba dated to 4200-4300 years ago (Damblon and Vanden Berghen 1993), and the occurrence of several bio-indicator plants suggests the former existence of sclerophyllous matorrals or open pre-steppic forests, with the possible presence of native Aleppo pine (Pinus halepensis) and olive tree (Olea europaea) on some of the largest islands (Médail et al. 2015). At present, keystone steppic shrubs (e.g. Lycium schweinfurthii, Periploca angustifolia, Rhus tripartita) are very rare on some islands or absent. The spiny summer-deciduous shrub Ziziphus lotus-the probable famous lotos of the Lotophagous island (Djerba) haunted in Homer's Odyssey - has totally disappeared from this large island during the first half of the twentieth century mainly because of wood collection by humans

Thus, if the natural flora and vegetation were precociously modified by humans, sea-level rise since at least 2000 years is about to lead to the ultimate coup de grace for the persistance of these original ecosystems of Eastern Tunisia

deposition) disturbances (e.g. Vidal et al. 2000; García et al. 2002). These impacts favours generally plant turnover, selection of some functional types with the massive establishment of annual, ruderal and cosmopolite or nonnative species (but see Panitsa et al. (2008) that did not detect any effect of gulls on richness or structure of plant communities for some E. Aegean islets). Detailed studies of these 'natural island microcosms' could indeed enhance our knowledge of functional and evolutionary processes induced by rapid environmental changes, at least for the biotic-simplified communities of the Mediterranean coasts.

\section{Conclusion}

Phylogenetical and phylogeographical results support the complex historical biogeography of the Mediterranean basin and also the importance of islands as reservoirs of unique genetic lineages, notably for most endemics and narrowly distributed plants (Médail and Diadema 2009; Nieto Feliner 2011). Nevertheless, the time frame and evolutionary consequences of biogeographical events linked to repeated cycles of connections and isolation of these continental islands, due to marine regressionstransgressions, remain largely unknown compared to oceanic islands (Weigelt et al. 2016). This is of particularly concern for efficient evolutionary conservation of these heterogeneous insular floras. With the ongoing biome crisis of the Mediterranean basin (Hoekstra et al. 2005), islands constitute indeed key ecological systems and 'current refugia' to ensure the conservation of coastal plant biodiversity. They are also key entities to disentangle the role of environmental versus human pressures in the long-term preservation of these biodiversity hotspots.

Because of increased threats across the Mediterranean region and the complex consequences of climate change 
(Klausmeyer and Shaw 2009), it is crucial to observe, monitor and analyse changes in vegetation and plant biodiversity across ecological and biogeographical gradients. Mediterranean islands, notably the small ones, are favourable sites for such long-term observations as well as for monitoring at various spatial scales. These 'natural island microcosms' are indeed appropriate systems to study adaptation to climate change by species or communities, and the functional biogeography approach (Violle et al. 2014) is undoubtedly an interesting topic that needs further research. The diversity of situations facing Mediterranean islands should facilitate their integration as laboratories or testing grounds of extinction in relation to global change and human pressures.

To this end, it would be useful to combine reactive approaches on the most threatened (often largest) islands, and proactive approaches on relatively less threatened islands, notably small islands and islets. Multi-disciplinary collaboration among prehistorians, archaeologists, palaeoecologists, historians, socio-economists, soil scientists, ecologists and biogeographers is needed to disentangle the complex interactions between past human societies and specific island environments. Enhancing these interdisciplinary research efforts is a prerequisite for the design of sound policies and practices concerning the conservation of these unique and fragile floras and plant communities (Médail 2013). The smallest islands should not be neglected, as they are often isolated territories where microspeciation processes occurs, offering modern refugeareas for diversity that is put at risk by the impacts of human activity on the coasts of the adjacent mainland.

Owing to their high biotic originality and vulnerability to global change, Mediterranean islands and islets urgently require integrated and ambitious conservation planning aimed at the long-term preservation of their outstanding biodiversity and cultural heritage.

\footnotetext{
Acknowledgements Some data concerning the small islands of eastern Tunisia and Corsica were obtained during several field missions funded by the PIM Initiative (Small Mediterranean Islands Initiative, www.initiative-pim.org) of the French Conservatoire $d u$ Littoral and by the Tunisian agency APAL (Agence de protection et d'aménagement du littoral) in 2014-2015. The French government (projet Investissements d'Avenir) within the Initiative d'excellence A*MIDEX/MEDNET (ANR-11-IDEX-0001-02) of Aix Marseille University also participated in the funding of some of these field trips (2013-2015). I thank my colleague Pr. Wolfgang Cramer (IMBE) for his invitation to write this review and for his useful comments on the manuscript, and to Dr. Salvatore Pasta (University of Fribourg) for his relevant comments and the fruitful discussions we had concerning the challenge of Mediterranean nissology. I thank Dr. Katia Diadema (Conservatoire botanique national méditerranéen) for her kind help concerning the realisation of the maps. Thanks also to an anonymous reviewer and to the editor of this paper, Dr. Erica Smithwick, for their recommendations which have improved a previous version of the manuscript.
}

\section{References}

Alcover JA (2008) The first Mallorcans: Prehistoric colonization in the western Mediterranean. J World Prehist 21:19-84

Arianoutsou-Faraggiraki M (1985) Desertification by overgrazing in Greece: the case of Lesvos island. J Arid Environ 9:237-242

Beffa G, Pedrotta T, Colombaroli D, Henne PD, van Leeuwen JFN, Süsstrunk P, Kaltenrieder P, Adolf C, Vogel H, Pasta S, Anselmetti FS, Gobet E, Tinner W (2016) Vegetation and fire history of coastal north-eastern Sardinia (Italy) under changing Holocene climates and land use. Veg Hist Archaeobot 25:271-289. doi:10.1007/s00334-015-0548-5

Bergmeier E, Dimopoulos P (2003) The vegetation of islets in the Aegean and the relation between the occurrence of islet specialists, island size, and grazing. Phytocoenologia 33:447-474. doi:10.1127/0340-269X/2003/0033-0447

Bittkau C, Comes HP (2005) Evolutionary processes in a continental island system: molecular phylogeography of the Aegean Nigella arvensis alliance (Ranunculaceae) inferred from chloroplast DNA. Mol Ecol 14:4065-4083. doi:10.1111/j.1365-294X.2005. 02725.X

Blondel J (2006) The 'design' of Mediterranean landscapes: a millennial story of humans and ecological systems during the historic period. Hum Ecol 34:713-729. doi:10.1007/s10745-0069030-4

Blondel J (2008) Humans and wildlife in Mediterranean islands. J Biogeogr 35:509-518. doi:10.1111/j.1365-2699.2007.01819.x

Blondel J, Médail F (2009) Biodiversity and conservation. In: Woodward JC (ed) The physical geography of the Mediterranean. Oxford University Press, Oxford, pp 615-650

Boillot F (1995) Tendances évolutives socio-économiques des îles de la Méditerranée. Ecol Medit 21:277-286

Bosque M, Adamogianni M-I, Bariotakis M, Fazan L, Stoffel M, Garfi G, Gratzfeld J, Kozlowski G, Pirintsos S (2014) Fine-scale spatial patterns of the Tertiary relict Zelkova abelicea (U1maceae) indicate possible processes contributing to its persistence to climate changes. Reg Environ Change 14:835-849. doi:10.1007/s10113-013-0544-1

Bottema S, Sarpaki A (2003) Environmental change in Crete: a 9000-year record of Holocene vegetation history and the effect of the Santorini eruption. The Holocene 13:733-749. doi:10. 1191/0959683603hl659rp

Broodbank C (2006) The origins and early development of Mediterranean maritime activity. J Medit Archaeol 19:199-230. doi:10. 1558//jmea.2006.v19i2.199

Brun P (1996) Les archipels égéens dans l'Antiquité grecque (Ve-IIe siècles av. notre ère). Ann litt Univ Franche-Comté 616:1-255

Brunel C, Sabatier F (2007) Pocket beach vulnerability to sea-level rise J Coastal Res SI 50 (proceed 9th intern coastal symposium), pp 604-609

Cazenave A, Dieng H-B, Meyssignac B, von Schuckmann K, Decharme B, Berthier E (2014) The rate of sea-level rise. Nat Clim Change 4:358-361. doi:10.1038/nclimate2159

Cerabolini B, Caccianiga M, Andreis C (1996) Secondary successions due to agricultural dereliction and post-fire recovery in the Mediterranean vegetation: first outlines in the western Elba (North Tyrrhenian sea-Italy). Coll Phytosociol 24:675-683

Church JA, White NJ (2011) Sea-level rise from the late 19th to the early 21st century. Surv Geophys 32:585-602. doi:10.1007/ s10712-011-9119-1

CIESM (2008) The Messinian salinity crisis from mega-deposits to microbiology. A consensus report. CIESM worshop monograph, $\mathrm{n}^{\circ} 33$, Monaco

Contandriopoulos J, Gamisans J (1974) À propos de l'élément arctico-alpin de la flore corse. Bull Soc Bot Fr 121:175-204 
Costa L-J (2004) Nouvelles données sur le Mésolithique des îles tyrrhéniennes (Corse et Sardaigne). Gall Préhist 46:211-230

Curtis EM, Gollan J, Murray BR, Leigh A (2016) Native microhabitats better predict tolerance to warming than latitudinal macroclimatic variables in arid-zone plants. J Biogeogr 43:1156-1165. doi:10.1111/jbi.12713

Damblon F, Vanden Berghen C (1993) Etude paléo-écologique (pollen et macrorestes) d'un dépôt tourbeux dans l'île de Djerba, Tunisie méridionale. Palynosciences 2:157-172

Diadema K, de Beaulieu J-L (2011) La mise en place de la flore. In: Noble V, Diadema K (eds) La flore des Alpes-Maritimes et de la Principauté de Monaco. Originalité et diversité, Naturalia Publications, Turriers, pp 23-33

Djamali M, Gambin B, Marriner N, Andrieu-Ponel V, Gambin T, Gandouin E, Lanfranco S, Médail F, Pavon D, Ponel P, Morhange C (2013) Vegetation dynamics during the early to mid-Holocene transition in NW Malta, human impact versus climatic forcing. Veg Hist Archaeobot 22:367-380. doi:10.1007/ s00334-012-0380-0

Economidou E (1995) L'appauvrissement de la flore et de la végétation des îles grecques, conséquence des activités humaines. Ecol Medit 21:299-304

Efstratiou N, Karetsou A, Ntinou N (2013) The Neolithic settlement of Knossos in Crete: New evidence for the early occupation of Crete and the Aegean Islands. INSTAP Academic Press, Philadelphia, Pennsylvania

Etienne L, Dahech S, Beltrando G, Daoud A (2012) Dynamiques récentes des sebkas littorales de l'archipel des Kerkennah (Tunisie centro-méridionale): apport de la télédétection. Rev Télédétection 11:273-281

Fernández-Mazuecos M, Jiménez-Mejías P, Rotllan-Puig X, Vargas P (2014) Narrow endemics to Mediterranean islands: moderate genetic diversity but narrow climatic niche of the ancient, critically endangered Naufraga (Apiaceae). Perspect Plant Ecol 16:190-202. doi:10.1016/j.ppees.2014.05.003

Galassi G, Spada G (2014) Sea-level rise in the Mediterranean Sea by 2050: roles of terrestrial ice melt, steric effects and glacial isostatic adjustment. Glob Planet Change 123:55-66. doi:10. 1016/j.gloplacha.2014.10.007

Gamisans J (1999) La végétation de la Corse (éd. 2). Edisud, Aix-enProvence

García D, Zamora R (2003) Persistence, multiple demographic strategies and conservation in long-lived Mediterranean plants. J Veg Sci 14:921-926. doi:10.1111/j.1654-1103.2003.tb02227.x

García LV, Marañón T, Ojeda F, Clemente L, Redondo R (2002) Seagull influence on soil properties, chenopod shrub distribution, and leaf nutrient status in semi-arid Mediterranean islands. Oikos 98:75-86. doi:10.1034/j.1600-0706.2002.980108.x

Gerasimidis A (2005) Deciduous oak forest vegetation history in Greece with emphasis on the effects of human impact as reflected by pollen diagrams. Bot Chron 18:117-133

Ghilardi M (dir) (2016) Géoarchéologie des îles de Méditerranée. Geoarchaeology of the Mediterranean islands. CNRS Editions, Paris

Gil M, Díaz-Fernández P (2003) La transformación histórica del paisaje forestal en las Islas Baleares. Ministerio de Medio Ambiente, Madrid

Giorgi F, Lionello P (2008) Climate change projections for the Mediterranean region. Glob Planet Change 63:90-104. doi:10. 1016/j.gloplacha.2007.09.005

Harris SE (2012) Cyprus as a degraded landscape or resilient environment in the wake of colonial intrusion. PNAS 109:3670-3675. doi:10.1073/pnas.1114085109

Henne PD, Elkin C, Franke C, Colombaroli D, Calò C, La Mantia T, Pasta S, Conedera M, Dermody O, Tinner W (2015) Reviving extinct Mediterranean forests communities may improve ecosystem potential in a warmer future. Front Ecol Environ 13:356-362. doi:10.1890/150027

Hilpold A, Schönswetter P, Susanna A, Garcia-Jacas N, Vilatersana R (2011) Evolution of the central Mediterranean Centaurea cineraria group (Asteraceae): evidence for relatively recent, allopatric diversification following transoceanic seed dispersal. Taxon 60:528-538

Hoekstra JM, Boucher TM, Ricketts TH, Roberts C (2005) Confronting a biome crisis: global disparities of habitat loss and protection. Ecol Lett 8:23-29. doi:10.1111/j.1461-0248.2004.00686.x

Hulme PE, Brundu G, Camarda I, Dalias P, Lambdon P, Lloret F, Médail F, Moragues E, Suehs CM, Traveset A, Troumbis A, Vilà M (2007) Assessing the risks to Mediterranean islands ecosystems from alien plant introductions. In: Tokarska-Guzik B, Brock JH, Brundu G, Child L, Daehler CC, Pyšek P (eds) Plant invasions: human perception, ecological impacts and management. Backhuys Publishers, Leiden, pp 39-56

Jaouadi S, Lebreton V, Bout-Roumazeilles V, Siani G, Lakhdar R, Boussoffara R, Dezileau L, Kallel N, Mannai-Tayech B, Combourieu-Nebout N (2016) Environmental changes, climate and anthropogenic impact in south-east Tunisia during the last 8 kyr. Clim Past 12:1339-1359. doi:10.5194/cp-12-1339-2016

Jeanmonod D, Schlüssel A, Gamisans J (2011) Status and trends in the alien flora of Corsica. OEPP/EPPO Bull 41:85-99. doi:10. $1111 / \mathrm{j} .1365-2338.2011 .02440 . \mathrm{x}$

Kadis K, Georghiou K (2010) Seed dispersal and germination behavior of three threatened endemic labiates of Cyprus. Plant Spec Biol 25:77-84. doi:10.1111/j.1442-1984.2009.00265.x

Kazakis G, Ghosn D, Vogiatzakis IN, Papanastasis VP (2007) Vascular plant diversity and climate change in the alpine zone of the Lefka Ori, Crete. Biodiv Conserv 16:1603-1615. doi:10. 1007/s10531-006-9021-1

Klausmeyer KR, Shaw MR (2009) Climate change, habitat loss, protected areas and the climate adaptation potential of species in Mediterranean ecosystems worldwide. PLoS ONE 4:e6392. doi:10.1371/journalpone0006392

La Mantia T, Carimi F, Di Lorenzo R, Pasta S (2011) The agricultural heritage of Lampedusa (Pelagie Archipelago, South Italy) and its key role for cultivar and wildlife conservation. Ital J Agron 6(e17):106-110. doi:10.4081/ija.2011.e17

Le Houérou HN (1990) Global change: vegetation, ecosystems, and land use in the southern Mediterranean basin by the mid twentyfirst century. Isr J Bot 39:481-508. doi:10.1080/ 0021213X.1990.10677170

Leighton R (1999) Sicily before history. An archeological survey from the Paleolithic to the Iron Age. Cornell University Press, Ithaca, New York

Leppard T (2014) Modeling the impacts of Mediterranean island colonization by archaic hominins: the likelihood of an insular lower Palaeolithic. J Med Archaeol 27:231-254. doi:10.1558/ jmea.v27i2.231

Leys B, Finsinger W, Carcaillet C (2014) Historical range of fire frequency is not the Achilles' heel of the Corsican black pine ecosystem. J Ecol 102:381-395. doi:10.1111/1365-2745.12207

Magny M, Peyron O, Sadori L, Ortu E, Zanchetta G, Vannière B, Tinner W (2012) Contrasting patterns of precipitation seasonality during the Holocene in the south- and north-central Mediterranean. J Quat Sci 27:290-296. doi:10.1002/jqs.1543

Maiorano L, Falcucci A, Zimmermann NE, Psomas A, Pottier J, Baisero D, Rondinini C, Guisan G, Boitani L (2011) The future of terrestrial mammals in the Mediterranean basin under climate change. Philos Trans R Soc B 366:2681-2692. doi:10.1098/rstb. 2011.0121

Mannino MA, Catalano G, Talamo S, Mannino G, Di Salvo R, Schimmenti V, Lalueza-Fox C, Messina A, Petruso D, Caramelli D, Richards MP, Sineo L (2012) Origin and diet of the 
prehistoric hunter-gatherers on the Mediterranean Island of Favignana (Egadi Islands, Sicily). PLoS ONE 7(11):e49802. doi:10.1371/journal.pone.0049802

Mansion G, Rosenbaum G, Schoenenberger N, Bacchetta G, Rosselló JA, Conti E (2008) Phylogenetic analysis informed by geological history supports multiple, sequential invasions of the Mediterranean Basin by the angiosperm family Araceae. Syst Biol 57:269-285. doi:10.1080/10635150802044029

Marull J, Tello E, Fullana N, Murray I, Jover G, Font C, Coll F, Domene E, Leoni V, Decolli T (2015) Long-term bio-cultural heritage: exploring the intermediate disturbance hypothesis in agroecological landscapes (Mallorca, c 1850-2012). Biodiv Conserv 24:3217-3251. doi:10.1007/s10531-015-0955-z

Mayol J (1995) Changements socio-économiques et conservation de la flore dans les îles de la Méditerranée. Ecol Medit 21:337-344

Médail F (2008) Ecosystems: Mediterranean. In: Jørgensen SE, Fath B (eds) Vol [3] of Encyclopedia of ecology, 5 vols. Elsevier, Oxford, pp 2296-2308

Médail F (2013) The unique nature of Mediterranean island floras and the future of plant conservation. In: Cardona Pons E, Estaún Clarisó I, Comas Casademont M, Fraga i Arguimbau P (eds) Islands and plants: preservation and understanding of flora on Mediterranean islands. In: 2nd Botanical conference in Menorca, Recerca 20, Consell Insular de Menorca, Institut Menorquí d'Estudis Maó, Menorca, pp 325-350

Médail F (2017) Plant biogeography and vegetation patterns of the Mediterranean islands. In: Corti $\mathrm{C}$ et al (eds) Herpetofauna of the Mediterranean islands. California Academy of Science, San Francisco (in press)

Médail F, Diadema K (2009) Glacial refugia influence plant diversity patterns in the Mediterranean basin. J Biogeogr 36:1333-1345. doi:10.1111/j.1365-2699.2008.02051.x

Médail F, Myers N (2004) Mediterranean Basin. In: Mittermeier RA, Robles Gil P, Hoffmann M, Pilgrim J, Brooks T, Mittermeier CG, Lamoreux J, da Fonseca GAB (eds) Hotspots revisited: Earth's biologically richest and most endangered terrestrial ecoregions. CEMEX (Monterrey), Conservation International (Washington), Agrupación Sierra Madre (Mexico), pp 144-147

Médail F, Quézel P (2003) Conséquences écologiques possibles des changements climatiques sur la flore et la végétation du bassin méditerranéen. Bocconea 16:397-422

Médail F, Pasta S, Chaieb M (2015) Flore et végétation des îles et îlots satellites de l'archipel des Kerkennah (Tunisie orientale). Bilan de la biodiversité végétale terrestre, impacts environnementaux et recommandations de gestion. Note naturaliste PIM, Aix-en-Provence. http://www.initiative-pim.org/sites/ default/files/fichier/documents/0000304W.pdf. Accessed 05 Oct 2016

Médail F, Charrier M, Charrier L, Chaieb M (2016) Flore et végétation des îles Kneiss (Tunisie sud-orientale). Bilan de la biodiversité végétale terrestre, impacts environnementaux et recommandations de gestion. Note naturaliste PIM, Aix-enProvence

Mee JA, Moore J-S (2014) The ecological and evolutionary implications of microrefugia. J Biogeogr 41:837-841. doi:10. 1111/jbi.12254

Molins A, Mayol M, Rosselló JA (2009) Phylogeographical structure in the coastal species Senecio rodriguezii (Asteraceae), a narrowly distributed endemic Mediterranean plant. J Biogeogr 36:1372-1383. doi:10.1111/j.1365-2699.2009.02108.x

Moragues E, Mayol J (2013) Managing threatened plants in islands: task and priorities. In: Cardona Pons E, Estaún Clarisó I, Comas Casademont M, Fraga i Arguimbau P (eds) Islands and plants: preservation and understanding of flora on Mediterranean islands. In: 2nd Botanical conference in Menorca, Recerca 20,
Consell Insular de Menorca, Institut Menorquí d'Estudis Maó, Menorca, pp 105-122

Nicholls RJ, Woodroffe C, Burkett V (2016) Coastal degradation as an indicator of global change. In: Letcher T (ed) Climate change: observed impacts on planet Earth, 2nd edn. Elsevier, Oxford, pp 309-324

Nieto Feliner G (2011) Southern European glacial refugia: a tale of tales. Taxon 60:365-372

Nikolić T, Antonić O, Alegro A, Dobrović I, Bogdanović S, Liber Z, Rešetnik I (2008) Plant species diversity of Adriatic islands: an introductory survey. Plant Biosyst 142:435-445. doi:10.1080/ 11263500802410769

Oueslati A (1995) Les îles de la Tunisie. Paysages et milieux naturels. Centre d'Etudes et de Recherches Economiques et Sociales (CERES), Série géographique, $\mathrm{n}^{\circ} 10$, Tunis

Panaïotis C, Barthet T, Vallauri D, Hugot L, Gauberville C, Reymann J, O'Deye-Guizien K, Delbosc P (2015) Notice de la carte d'État-major de la Corse. Occupation du sol et première analyse des forêts anciennes. Conservatoire botanique national de Corse-Office de l'Environnement de la Corse, WWF France, Corte

Panitsa M, Tzanoudakis D, Sfenthourakis S (2008) Turnover of plants on small islets of the eastern Aegean Sea within two decades. J Biogeogr 35:1049-1061. doi:10.1111/j.1365-2699.2007.01846.x

Papanastasis VP, Kyriakakis S, Kazakis G (2002) Plant diversity in relation to overgrazing and burning in mountain Mediterranean ecosystems. J Medit Ecol 3:53-63

Paschou P, Drineas P, Yannaki E, Razoud A, Kanaki K, Tsetsos F, Padmanabhuni SS, Michalodimitrakis M, Renda MC, Pavlovic S, Anagnostopoulos A, Stamatoyannopoulos JA, Kenneth KK, Stamatoyannopoulos G (2014) Maritime route of colonization of Europe. PNAS 111:9211-9216. doi:10.1073/pnas.1320811111

Pausas JG, Fernández-Muñoz S (2012) Fire regime changes in the Western Mediterranean basin: from fuel-limited to droughtdriven fire regime. Clim Change 110:215-226. doi:10.1007/ s10584-011-0060-6

Pausas JG, Keeley JE (2014) Abrupt climate-independent fire regime changes. Ecosystems 17:1109-1120. doi:10.1007/s10021-0149773-5

Penuelas J, Filella I, Comas P (2002) Changed plant and animal life cycles from 1952 to 2000 in the Mediterranean region. Glob Change Biol 8:531-544. doi:10.1046/j.1365-2486.2002.00489.x

Pérez-Obiol R, Sadori L (2007) Similarities and dissimilarities, synchronisms and diachronisms in the Holocene vegetation history of the Balearic Islands and Sicily. Veg Hist Archaeobot 16:259-265. doi:10.1007/s00334-006-0038-x

Petanidou T, Kizos T, Soulakellis N (2008) Socioeconomic dimensions of changes in the agricultural landscape of the Mediterranean basin: a case study of the abandonment of cultivation terraces on Nisyros Island, Greece. Environ Manag 41:250-266. doi:10.1007/s00267-007-9054-6

Pirazzoli PA (1986) Secular trends of relative sea level (RSL) changes indicated by tide-gauge record. J Coast Res Spec Issue $1: 1-26$

Poher Y, Ponel P, Médail F, Andrieu-Ponel V, Guiter F (2017a) Holocene environmental history of a small Mediterranean island in response to sea-level changes, climate and human impact. Palaeogeogr Palaeoclim Palaeoecol 465:247-263. doi:10.1016/j. palaeo.2016.10.037

Poher Y, Ponel P, Guiter F, Andrieu-Ponel V, Médail F (2017b) Erosion of insect diversity in response to 7000 years of relative sea-level rise on a small Mediterranean island. Biodiv Conserv. doi: 10.1007/s10531-017-1322-z

Pretto F, Celesti-Grapow L, Carli E, Brundu G, Blasi C (2012) Determinants of non-native plant species richness and 
composition across small Mediterranean islands. Biol Invasions 14:2559-2572. doi:10.1007/s10530-012-0252-7

Puddu S, Podda L, Mayoral O, Delage A, Hugot L, Petit Y, Bacchetta $G$ (2016) Comparative analysis of the alien vascular flora of Sardinia and Corsica. Not Bot Hortic Agrobot 44:337-346. doi: $10.15835 /$ nbha44210491

Quézel P, Médail F (2003) Écologie et biogéographie des forêts du bassin méditerranéen (collection environnement). Elsevier, Paris

Rackham O, Moddy J (1996) The making of the Cretan landscape. Manchester University Press, Manchester

Ranis GR, Iakovoglou V, Zaimes GN (2015) Ecosystem post-wildfire effects of Thasos Island. Intern $\mathrm{J}$ Environ Chem Ecol Geol Geophys Eng 9:1201-1204

Rosselló J (2013) A perspective of plant microevolution in the Western Mediterranean islands as assessed by molecular markers. In: Cardona Pons E, Estaún Clarisó I, Comas Casademont M, Fraga i Arguimbau P (eds) Islands and plants: preservation and understanding of flora on Mediterranean islands. 2nd Botanical conference in Menorca, Recerca 20, Consell Insular de Menorca, Institut Menorquí d'Estudis Maó, Menorca, pp 21-34

Rotllan-Puig X, Traveset A (2016) Declining relict plants: climate effect or seed dispersal disruption? A landscape-scale approach. Basic Appl Ecol 17:81-91. doi:10.1016/j.baae.2015.08.003

Rowley-Conwy P, Gourichon L, Helmer D, Vigne J-D (2013) Early domestic animals in Italy, Istria, the Tyrrhenian islands and Southern France. In: Colledge S, Conolly J, Dobney K, Manning $\mathrm{K}$, Shennan S (eds) The origins and spread of domestic animals in southwest Asia and Europe. Left Coast Press, Walnut Creek, pp 161-194

Rühl J, Pasta S (2008) Plant succession on Sicilian terraces. Annali di Botanica nuov ser 7:111-126

Runnels C (2014) Early Palaeolithic on the Greek islands? J Med Archaeol 27:211-230. doi:10.1558/jmea.v27i2.211

Schaich H, Kizos T, Schneider S, Plieninger T (2015) Land change in Eastern Mediterranean wood-pasture landscapes: the case of decidous oak woodlands in Lesvos (Greece). Environ Manag 56:110-126. doi:10.1007/s00267-015-0496-y

Simmons AH (2014) Stone age sailors. Paleolithic seafaring in the Mediterranean. Left Coast Press, Walnut Creek

Slim H, Trousset P, Paskoff R, Oueslati A (2004) Le littoral de la Tunisie Étude géoarchéologique et historique. CNRS Editions, Paris

Snogerup S (1967) Studies in the Aegean flora. IX. Erysimum sect. Cheiranthus. B. Variation and evolution in the smallpopulation system. Opera Bot 14:1-86

Thirgood JV (1981) Man and the Mediterranean forest. A history of resource depletion. Academic Press, London

Traveset A, Brundu G, Carta L, Mprezetou I, Lambdon P, Manca M, Médail F, Moragues E, Rodríguez-Pérez J, Siamantziouras ASD, Suehs CM, Troumbis AY, Vilà M, Hulme PE (2008) Consistent performance of invasive plant species within and among islands of the Mediterranean basin. Biol Invasions 10:847-858. doi:10. 1007/s10530-008-9245-y

Triantis K, Mylonas M (2009) Greek islands, biology. In: Gillespie RG, Clague DA (eds) Encyclopedia of islands. University of California Press, Berkeley, pp 388-392

Trousset P, Slim H, Paskoff R, Oueslati A (1992) Les îles Kneiss et le monastère de Fulgence de Ruspe. Antiquités africaines 28:223-247

Trump DH (2008) Malta prehistory and temples. 3rd edn. Midsea Books Ltd, La Valette, Malta

Tzedakis PC (2009) Cenozoic climate and vegetation change in the Mediterranean basin. In: Woodward JC (ed) The physical geography of the Mediterranean. Oxford University Press, Oxford, pp 89-137

Vacchi M, Marriner N, Morhange C, Spada G, Fontana A, Rovere A (2016) Multiproxy assessment of Holocene relative sea-level changes in the western Mediterranean: sea-level variability and improvements in the definition of the isostatic signal. Earth-Sci Rev 155:172-197. doi:10.1016/j.earscirev.2016.02.002

Verlaque R, Contandriopoulos J, Aboucaya A (1995) Cytotaxonomie et conservation de la flore insulaire: les espèces endémiques ou rares de Corse. Ecol Medit 21:257-268

Vidal E, Médail F, Tatoni T, Bonnet V (2000) Seabirds drive plant species turnover on small Mediterranean islands at the expense of native taxa. Oecologia 122:427-434. doi:10.1007/ s004420050049

Vigne J-D (1999) The large 'true' Mediterranean islands as a model for the Holocene human impact on the European vertebrate fauna? Recent data and new reflections. In: Benecke N (ed) The Holocene history of the European vertebrate fauna. Modern aspects of research. Deutsches Archäologisches Institut (Archäologie in Eurasien 6). Eurasien-Abteilung, Berlin, pp 295-322

Vigne J-D (2014) The origins of mammals on the Mediterranean islands as an indicator of early voyaging. Eurasian Prehist $10: 45-56$

Vigne J-D, Briois F, Zazzo A, Willcox G, Cucchi T, Thiébault S, Carrère I, Franel Y, Touquet R, Martin C, Moreau C, Comby C, Guilaine J (2012) First wave of cultivators spread to Cyprus at least 10,600 y ago. PNAS 109:8445-8449. doi:10.1073/pnas. 1201693109

Vilà M, Tessier M, Suehs CM, Brundu G, Carta L, Galanidis A, Lambdon P, Manca M, Médail F, Moragues E, Traveset A, Troumbis AY, Hulme PE (2006) Local and regional assessments of the impacts of plant invaders on vegetation structure and soil properties of Mediterranean islands. J Biogeogr 33:853-861. doi:10.1111/j.1365-2699.2005.01430.x

Violle C, Reich PB, Pacala SW, Enquist BJ, Kattge J (2014) The emergence and promise of functional biogeography. PNAS 111:13690-13696. doi:10.1073/pnas.1415442111

Vogiatzakis IN, Pungetti G, Mannion AM (eds) (2008) Mediterranean island landscapes. Natural and cultural approaches. Landscape series, vol 9. Springer, New York

Weigelt P, Steinbauer MJ, Cabral JS, Kreft H (2016) Late Quaternary climate change shapes island biodiversity. Nature 532:99-102. doi:10.1038/nature 17443

Westberg E, Kadereit JW (2009) The influence of sea currents, past disruption of gene flow and species biology on the phylogeographical structure of coastal flowering plants. J Biogeogr 36:1398-1410. doi:10.1111/j.1365-2699.2008.01973.x

Whittaker RJ, Fernández-Palacios JM (2007) Island biogeography: ecology, evolution, and conservation, 2nd edn. Oxford University Press, Oxford

Woodward JC (ed) (2009) The physical geography of the Mediterranean. Oxford University Press, Oxford

Woolbright SA, Whitham TG, Gehring CA, Allan GJ, Bailey JK (2014) Climate relicts and their associated communities as natural ecology and evolution laboratories. Trends Ecol Evol 29:406-416. doi:10.1016/j.tree.2014.05.003

Zazzo A, Lebon M, Quiles A, Reiche I, Vigne J-D (2015) Direct dating and physico-chemical analyses cast doubts on the coexistence of humans and dwarf hippos in Cyprus. PLoS ONE 10(8):e0134429. doi:10.1371/journal.pone.0134429

Zeder MA (2008) Domestication and early agriculture in the Mediterranean basin: Origins, diffusion, and impact. PNAS 105:11597-11604. doi:10.1073/pnas.0801317105 